\title{
Prevalence of Hepatitis B, C and Tuberculosis in Under Privileged Children (Orphans) of District Bagh, Azad Jammu and Kashmir
}

\author{
Samina Tahir Kiani ${ }^{1}$, Abdul Rauf ${ }^{1}$, Syed Ayaz Kazmi ${ }^{1, *}$, Nuzhat Shafi ${ }^{1}$, \\ Madiha Khalid ${ }^{2}$, Naeem Latif ${ }^{1}$, Samina Gul², Saghir Yousaf ${ }^{3}$ and \\ Muhammad Arshad ${ }^{4}$ \\ ${ }^{1}$ Department of Zoology, University of Azad Jammu and Kashmir, Muzaffarabad \\ ${ }^{2}$ Department of Biotechnology, University of Azad Jammu and Kashmir, Muzaffarabad \\ ${ }^{3}$ Help in Need, Sector G-8, Islamabad \\ ${ }^{4}$ Department of Bioinformatics and Biotechnology, International Islamic University, \\ Islamabad
}

\begin{abstract}
A B S T R A C T
Present work describes the prevalence of above-mentioned diseases in underprivileged orphans of District Bagh, Azad Jammu and Kashmir. Blood samples of a total of 300 children (150 males and 150 females), 4-17 years of age were screened for anti-HCV antibody, HBsAg and anti-MTB antibodies using ICT kits. Sputum microscopy for MTB was done in MTB antibody positive samples. The samples positive in initial screening were confirmed by enzyme linked immunosorbent assay (ELISA) and polymerase chain reaction (PCR). Nine samples were found positive in both ICT and ELISA test for HCV while PCR showed six positive cases for HCV. HBV were found positive in three samples after ICT and ELISA, but was found negative after PCR. MTB was found positive in seven cases after ICT, while six gave positive PCR. Blood transfusion $(\mathrm{p}=0.0001)$ was found significant risk factor regarding spread of hepatitis B and $\mathrm{C}$ in the studied population.
\end{abstract}

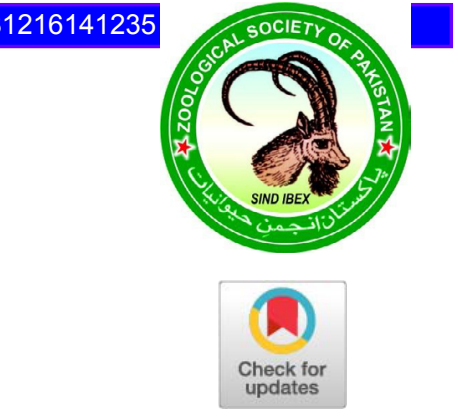

\section{INTRODUCTION}

$\mathrm{H}$ epatitis is the inflammation of the liver and is described through the provocative cells manifestation in the tissue (Reddy et al., 2012). Globally, the Hepatitis B virus (HBV) which causes Hepatitis B is posing notable health issue with the condition more critical in Latin America, Europe, Asia, and southern Africa. About 1.2 million deaths occur annually due to hepatitis B and it is the tenth principal cause of deaths worldwide (Mahoney, 1999; Lee, 1997). Of the 2 billion infected individuals, more than 350 million are chronic carriers of this virus (WHO, 2000). Blood transfusions, tattooing, acupuncture, dialysis, prolonged overseas travel and working in a healthcare setting are the possible risk factors for contracting Hepatitis B (Kidd et al., 2006; Ghany et al., 2009).

Hepatitis $\mathrm{C}$ is a complex disease caused by the Hepatitis C Virus that primarily targets the liver. Human is the only identified natural host of HCV (Sharma, 2010). Globally 130-200 million population is infected with hepatitis C (Gravitz, 2011). The overall HCV prevalence

\footnotetext{
Corresponding author: ayaz.biotech.uajk@gmail.com 0030-9923/2021/0005-1897 \$ 9.00/0

Copyright 2021 Zoological Society of Pakistan
}

in Pakistan is 5\% (Wahid et al., 2011). HCV mainly transmitted through blood transfusion, and injection-drug use before 1990, the transmission of $\mathrm{HCV}$ is significantly reduced by blood donor screening for HCV since 1990 (Alter et al., 1999). In Pakistan, the prevalence of HCV is higher than in other areas of the world (Idrees et al., 2009). Hepatitis $C$ frequency is greater in the provinces of Punjab and Sindh as compared to KPK, Baluchistan and Azad Jammu and Kashmir (Butt and Amin, 2008).

Tuberculosis or TB is fatal infectious illness occurs due to different strains of Mycobacteria, especially Mycobacterium tuberculosis (Kumar et al., 2007). Globally, TB is one of the top three killers of women: in 2010 approximately 580,000 women were killed by TB leaving many children and families vulnerable. About 9.7 million children have been orphaned by losing one of

\section{Abbreviations}

cDNA, complementary deoxyribonucleic acid; HBsAg, hepatitis B surface antigen; Anti-HCV, antihepatitis $\mathrm{C}$ virus antibody; HBV, hepatitis B virus; $\mathrm{HCV}$, hepatitis $\mathrm{C}$ virus; ICT, immuno chromatographic technique; PCR, polymerase chain reaction; RT-PCR, real time polymerase chain reaction; N/A, not applicable; DHQ, District Headquarters. 
their parents to TB (WHO, 2011). China, Bangladesh, Indonesia, Pakistan, and India collectively account for half of the world TB infection, while high frequency is reported in sub-Saharan Africa (WHO, 2009) Pakistan position eighth amongst the countries with maximum TB infection globally (Shamsi et al., 2008). It has an aerial route of transmission, coughing, sneezing or respiratory fluids from a person having active TB infection are its primary routes of TB spread (Konstantinos, 2011). The poorest and most marginalized groups are the chief target of TB (WHO, 2010). Thus, the present study was designed to estimate the prevalence of hepatitis B, C, and TB among the most deprived fraction of society.

\section{MATERIALS AND METHODS}

\section{Population distribution and data collection}

The study was conducted on 300 male and female underprivileged orphans with age range of 4-17 years from District Bagh. Hepatitis B, C and Tuberculosis screening study was carried out on mom less and malnourished orphans living in shelter. Screening camps were organized in Bagh, Thub and Dhulli localities of District Bagh. Besides screening for antibody and antigen against these viruses, related symptoms including cough, flu, sore throat, allergy, anemia, jaundice and BMI were recorded.

\section{Sampling and initial screening}

After that $5 \mathrm{ml}$ of blood was collected from each participant and injected into the gel tube (Biotube Gel Clot Activator). Serum was separated by centrifugation. Each serum sample was labeled and stored at $-20^{\circ} \mathrm{C}$. The hepatitis B surface antigen (HBsAg), hepatitis C virus antibody (anti-HCV) and anti-MTB antibodies were detected by using Immuno Chromatographic Technique (ICT) through ICT devices (SD BIOLINE HBsAg, AntiHCV and anti-MTB kits).

\section{HBV DNA extraction and amplification}

From the serum of HBsAg positive people, viral DNA was isolated by using the remoulded DNAzol method previously used by Wanderlei-Silva et al. (2005). The amplification of HBV DNA is being performed by using Favor-PrepTM Viral DNA purification kit (Favorgen ${ }^{\circledR}$, Biotech Corp, USA) and Thermo-Start Taq DNA Polymerase Kit (Thermo Scientific ${ }^{\circledR}$, USA) which is a highly sensitive (quantification rage was $100 \mathrm{IU} / \mathrm{ml}$ to $150,000,000 \mathrm{IU} / \mathrm{ml})$. Confirmation of PCR amplification was further done by Gel-Electrophoresis.

\section{HCV RNA extraction, amplification and genotyping}

Viral RNA was also isolated from the serum of anti-
$\mathrm{HCV}$ antibody positive individuals through reformed TRIzol RNA Isolation Protocol previously used by Chomczynski and Mackey (1995). The RT PCR for HCV RNA is being performed using Favor-PrepTM Viral purification kit (Favorgen ${ }^{\circledR}$, Biotech Corp, USA) and Verso 1-Step RT-PCR Hot Start Kit (Thermo Scientific $\AA$, USA) that does the real-time amplification of $5^{\prime}$ UTR of HCV genome by using a set of specific primers previously used by Casanova et al. (2014). The quantification range of the assay was $100 \mathrm{IU} / \mathrm{ml}$ to $350,000,000 \mathrm{IU} / \mathrm{ml}$. HCV RNA of genotypes 1a, 1b, 2a, 2b, 2c, 3a, 3b, 4, 5a and 6 were amplified with similar efficiency. PCR amplification was further confirmed by Gel Electrophoresis.

The genotypes of HCV were identified with multiplexPCR by following the protocol of Ohno et al. (1997). Two reaction mixtures containing two sets of primers each were processed in parallel in the nested PCR. PCR-thermocycler was adjusted at $94^{\circ} \mathrm{C}$ for denaturation for $5 \mathrm{~min}$, followed by 30 cycles, each of $30 \mathrm{sec}$ at $94^{\circ} \mathrm{C}$ (denaturation), 40 $\mathrm{sec}$ at $64^{\circ} \mathrm{C}$ (annealing) and $30 \mathrm{sec}$ at $72^{\circ} \mathrm{C}$ (extension) with final extension at $72^{\circ} \mathrm{C}$ for $5 \mathrm{~min}$. The nested PCR was carried out under the same PCR conditions as above, except for the annealing temperature which was $53^{\circ} \mathrm{C}$.

\section{Sputum microscopy for MTB}

Sputum microscopy for ICT-MTB positive individuals were performed by using the method reported by Van et al. (2010) under LED compound microscope.

\section{PCR for MTB}

For confirmation of TB in the above screened positive samples, $250 \mu \mathrm{L}$ of blood sample was mixed with $500 \mu \mathrm{L}$ of DNAzol ${ }^{\circledR B D}$. Cat. No. DN129 (a Product of Molecular Research Centre, Inc., Cincinnati, OH, USA) for DNA isolation. The protocol was previously followed by Rauf et al. (2013). The isolated DNA was dissolved in $50 \mu \mathrm{L}$ of nuclease free water and used as template in the Polymerase Chain Reaction (PCR) for the detection of Mycobacterium tuberculosis.

Following set of reverse and forward primers was used in the PCR amplification of Mycobacterium TB DNA: TB-1 5' GTG CGG ATG GTC GCA GAG AT 3', TB-2 5' CTC GTC CAG CGC CGC TTC G 3', TB-3 5' CTC GAT GCC CTC ACG GTT CA 3' and TB-4 5' CCT GCG AGC GTA GGC GTC GG 3'

\section{Previous medical history and risk factors assessment}

A specifically designed questionnaire was used to record the previous life history to assess the risk factors for hepatitis and tuberculosis of individuals in the selected population. The questionnaire consisted of general information of participants including gender, 
name, locality, address, and risk factors for hepatitis such as history of drug use, blood transfusion, any surgery, dental procedure, tattooing, unsterilized hair cutting or shaving, nose or ear piercing, accidental cut, tooth brush or comb sharing, medical care, unsterilized parlor treatment etc. For risk factors assessment of Tuberculosis, same questionnaire was developed containing general information and risk factors for TB including history of exposure to TB patient, TB symptoms, living style, use of inhaler, exposure to smoke, use of milk products, number of windows in room, contacts with cattle, intestinal bypass and other related factors.

\section{Statistical analysis}

Data were statistically analyzed for the calculation of mean age with $95 \%$ Confidence Interval and frequency distribution. For all the calculation we used GraphPad Prism (Version 5.0) software.

\section{RESULTS}

\section{Prevalence of $\mathrm{HBV}, \mathrm{HCV}$ and tuberculosis}

In the present study, of 300 underprivileged orphan children $(150 \mathrm{M}$ and $150 \mathrm{~F})$ of age ranging from 4 to 17 years, 03 cases $(1.00 \%)$ were found positive for $\mathrm{HBsAg}$, 9 children $(3.00 \%)$ were found positive for Anti-HCV antibodies while seven cases $(2.33 \%)$ appeared positive for MTB antibodies. HBsAg was found in two males $(1.33 \%)$ and one female $(0.66 \%)$, Anti HCV antibody was found in four males $(2.66 \%)$ and five females $(3.33 \%)$ while three males $(2.00 \%)$ and four females $(2.66 \%)$ were found positive for MTB antibody. PCR confirmation was done for respective DNA/RNA of the target pathogen. No positive case of HBV DNA while $6(2.00 \%)$ participants were found positive for HCV through PCR amplification. Of 7 positive samples for TB, six samples $(2 \%$ of total) appeared positive in both sputum microscopy and PCR. Table I shows the percent prevalence of HBsAg, Anti $\mathrm{HCV}$ and Anti MTB in the studied population.

Table I.- Prevalence of HBV, HCV and TB in orphan children.

\begin{tabular}{lccc}
\hline & Overall & Male & Female \\
\hline Anti HCV & $9(3.0 \%)$ & $4(2.66 \%)$ & $5(3.33 \%)$ \\
HCV PCR & $6(2.00 \%)$ & $3(2.00 \%)$ & $3(2.00 \%)$ \\
Anti HBsAg & $3(1.0 \%)$ & $2(1.33 \%)$ & $1(0.66 \%)$ \\
HBV PCR & $0(0.0 \%)$ & $0(0.0 \%)$ & $0(0.0 \%)$ \\
Anti MTB & $7(2.33 \%)$ & $3(2.0 \%)$ & $4(2.66 \%)$ \\
MTB sputum & $6(2.0 \%)$ & $3(2.0 \%)$ & $3(2.0 \%)$ \\
microscopy & & & \\
MTB PCR & $6(2.0 \%)$ & $3(2.0 \%)$ & $3(2.0 \%)$ \\
\hline
\end{tabular}

Prevalence on the basis of locality and related disorders

The study area was divided in three localities namely Thub, Bagh and Dhulli areas of District Bagh, Azad Jammu and Kashmir. The prevalence of HBV in Thub, Bagh and Dhulli was found to be $(\mathrm{n}=2 ; 0.66 \%$ of total $),(\mathrm{n}=1 ; 0.330 \mathrm{f}$ total) and $(n=0 ; 0.00 \%$ of total), respectively. Highest prevalence of HCV was found in Thub $(n=4 ; 1.33 \%$ of total), while number of $\mathrm{HCV}$ infected individuals in Bagh and Dhulli were $(n=2 ; 0.66 \%$ of total) and $(n=3 ; 1.00 \%$ of total), respectively. Similarly, highest prevalence of TB infection ( $\mathrm{n}=4 ; 1.33 \%$ of total) was observed in Thub locality, while the number of TB infected individuals in Bagh and Dhulli localities was $1(0.33 \%$ of total) and 2 $(0.66 \%$ of total), respectively. Flu, sore throat, jaundice, anemia, skin allergy, cough and scabies were found related disorders in MTB positive cases. Table II shows the locality-based prevalence of studied diseases in the population.

Table II.- Prevalence of $\mathrm{HBV}, \mathrm{HCV}, \mathrm{TB}$ and related disorders on the basis of locality.

\begin{tabular}{lcccl}
\hline Locality & HBV & HCV & TB & \multicolumn{2}{l}{ Related disorders } \\
\hline Thub & $2(0.66 \%)$ & $4(1.33 \%)$ & $4(1.33 \%)$ & Cough, flu, sore \\
Bagh & $1(0.33 \%)$ & $2(0.66 \%)$ & $1(0.33 \%)$ & throat, jaundice, \\
anemia, skin allergy, \\
Dhulli & $0(00 \%)$ & $3(1.00 \%)$ & $2(0.66 \%)$ & cough and scabies \\
\hline
\end{tabular}

Table III.- Prevalence of $\mathrm{HBV}, \mathrm{HCV}$ and TB on the basis of age group.

\begin{tabular}{lcccc}
\hline $\begin{array}{l}\text { Age } \\
\text { group }\end{array}$ & $\begin{array}{c}\text { Mean age with } \\
\text { 95\% CI }\end{array}$ & HBV & HCV & TB \\
\hline $4-8$ & $5.818 \pm 0.291$ & $0(0.0 \%)$ & $2(22.22 \%)$ & $2(28.57 \%)$ \\
$9-12$ & $10.31 \pm 0.190$ & $2(66 \%)$ & $4(44.44 \%)$ & $3(42.86 \%)$ \\
$13-17$ & $14.64 \pm 0.240$ & $1(33 \%)$ & $3(33.33 \%)$ & $2(28.57 \%)$ \\
\hline
\end{tabular}

Prevalence of $T B$ in relation to age

The prevalence of $\mathrm{HBV}, \mathrm{HCV}$ and $\mathrm{TB}$ was also estimated on the basis of different age groups. Results showed that the highest HCV prevalence $(n=4 ; 44.44 \%)$ was reported among the children of age ranging from 9-12 years, while in age group of 4-8 and 13-17, number of HCV infected individuals were $(n=2 ; 22.22 \%)$ and $(n=3$; $33.33 \%$ ), respectively. Similarly, prevalence of $\mathrm{HBV}$ in age groups of $9-12$ and $13-17$ was $(n=2 ; 66 \%)$ and $(n=1$; $33 \%)$. No case was found positive for HBV in age group of 4-8. The prevalence of TB was highest $(n=3 ; 42 \%)$ among the children of age $9-12$ years. while the prevalence of TB in other two groups (4-8 and 13-17 years of age) was equal $(n=2 ; 28 \%)$. Table III shows the prevalence of the disease on the basis of different age groups. 
Correlation of tuberculosis with body mass index (BMI)

Among tuberculosis positive children no $(\mathrm{n}=00)$ overweight case was found while 5 children (1.66\%) with tuberculosis were underweight having low BMI with below average growth and health conditions. Average BMI among the 5 TB positive children was 15.04 with the range of 12.9-16.8. These children were moderately to severely underweight and belonged to Thub $(\mathrm{n}=03)$ and Dhulli $(\mathrm{n}=$ 02) localities. Table IV shows the correlation of TB and BMI in the studied population.

\section{Risk factors}

Risk factors regarding hepatitis B and C were assessed through questionnaire method and were analyzed under GraphPad Prism (Version 5.0). Injections history, sharing of personal belongings, and Haircut from Barber/Beautician were found in $100 \%$ population, so the Chi-square test was found not applicable on these factors. While, Tattooing or piercing of nose, ears etc. $(\mathrm{p}=0.0752)$ were found not significant risk factors, and Blood transfusion $(\mathrm{p}=0.0001)$ was found significant risk factor regarding spread hepatitis $\mathrm{B}$ and $\mathrm{C}$ in the studied population (Table V).

\section{DISCUSSION}

The current study was done to assess the Hepatitis $\mathrm{B}$ and $\mathrm{C}$ prevalence and co-infection with TB in District Bagh, Azad Jammu and Kashmir during the year 2014. The size of the total population screened was 300 individuals. The results showed high prevalence of hepatitis $\mathrm{C}$ and Tuberculosis while hepatitis B was found to be less prevalent in the studied population. The results revealed that among the total population, $5(3.33 \%)$ female individuals and 4 (2.66) male individuals were found positive for $\mathrm{HCV}$ in ICT, of which 3 female and 3 male were confirmed positive for $\mathrm{HCV}$ through PCR testing. Similarly, $\mathrm{HBsAg}$ was found in two males $(1.33 \%)$ and one female $(0.66 \%)$, which appeared negative when confirmed through PCR. These results were found similar to the findings of Qureshi et al. (2010), where hepatitis B surface antigen (HBsAg) prevalence was found lower $(2.5 \%)$, than anti-hepatitis $\mathrm{C}$ virus $(4.8 \%)$. Similarly, these results were also supported through the study directed by Umair et al. (2012) in which they reported Hepatitis-B and $\mathrm{C}$ prevalence in blood donors of District Mirpur Azad Kashmir as about 1.68 and $2.5 \%$, respectively. The results were also in agreement with that of Mostafa et al. (2001) in which the estimated HCV prevalence among males and females was equal (24.3\%). However, these results were different from those reported by Rauf et al. (2013) in which the estimated prevalence of $\mathrm{HCV}$ in under privileged orphans was high in males than females; 5.5 and $4.1 \%$, respectively.

The present study, was also conducted to diagnose the related disorders, including weight, growth and health conditions, results indicated that individual suffering from HCV infection $(\mathrm{n}=01)$, mild and severe cough and physical weakness, all five children who appeared positive with TB had low BMI and were underweight. Our results supported by the study of Leung et al. (2007) who had reported that low BMI is an important risk factor for developing TB.

Table IV.- Correlation of tuberculosis with BMI in the studied population (children).

\begin{tabular}{lccc}
\hline Cluster & Total & Overweight (\%) & Weak (\%) \\
\hline Thub & 100 & $0(00 \%)$ & $3(60 \%)$ \\
Bagh & 100 & $0(00 \%)$ & $0(00 \%)$ \\
Dhulli & 100 & $0(00 \%)$ & $2(40 \%)$ \\
\hline
\end{tabular}

Table V.- Risk factor assessment for hepatitis B and C.

\begin{tabular}{|c|c|c|c|c|c|c|}
\hline $\begin{array}{l}\text { S. } \\
\text { No. }\end{array}$ & Factors & Responses & $\begin{array}{c}\text { Total } \\
\text { assessments }\end{array}$ & $\begin{array}{c}\text { Responses of positive } \\
\text { population }\end{array}$ & $\begin{array}{c}\text { Responses of negative } \\
\text { population }\end{array}$ & $\begin{array}{c}\text { Chi-squar } \\
\text { P-value (0.05) }\end{array}$ \\
\hline \multirow[t]{2}{*}{1} & \multirow[t]{2}{*}{ Injections history } & Yes & 300 & 12 & 288 & N/A \\
\hline & & No & 0 & 0 & 0 & \\
\hline \multirow[t]{2}{*}{2} & \multirow{2}{*}{$\begin{array}{l}\text { Tooth brush, razor, comb } \\
\text { and nail cutter sharing }\end{array}$} & Yes & 300 & 12 & 288 & N/A \\
\hline & & No & 0 & 0 & 0 & \\
\hline \multirow[t]{2}{*}{3} & \multirow{2}{*}{$\begin{array}{l}\text { Haircut from barber/ } \\
\text { beautician }\end{array}$} & Yes & 300 & 12 & 288 & N/A \\
\hline & & No & 0 & 0 & 0 & \\
\hline \multirow[t]{2}{*}{4} & \multirow{2}{*}{$\begin{array}{l}\text { Tattooing or piercing of } \\
\text { nose, ears etc. }\end{array}$} & Yes & 143 & 09 & 134 & 0.0752 \\
\hline & & No & 157 & 03 & 154 & \\
\hline \multirow[t]{2}{*}{5} & Blood transfusion & Yes & 07 & 05 & 02 & 0.0001 \\
\hline & & No & 293 & 07 & 286 & \\
\hline
\end{tabular}


The current study determined the estimated prevalence of TB. The total seven cases found positive in ICT and 6 in sputum microscopy were confirmed through PCR. The overall percentage prevalence of TB according to immuno chromatographic (ICT) technique was $2.33 \%$, whereas on the basis of sputum microscopy and PCR the percentage prevalence of TB was found to be same (2\%). Our findings were similar to Rauf et al. (2013) who also reported high percentage prevalence $(8.3 \%)$ of TB in underprivileged orphan children. Similar to our findings, Syed et al. (2012) reported the percentage of all TB cases occurring in children ranges from $3-25 \%$. The results indicated that among the total population studied, the estimated prevalence of HCV and TB was high as compared to HBV. Our results are also supported by the Taura et al. (2013) which showed that HCV co-infection with TB is higher $(14.8 \%)$ than HBV $(8.7 \%)$.

It was also observed that Thub locality had high number $(\mathrm{n}=04)$ of TB infected individuals, while the number of TB effected individuals in Bagh and Dhulli locality was 1 and 2, respectively. The results revealed that in Thub locality number of male and female individuals effected with TB was same $(n=04)$, in Bagh locality only one female was reported positive for $\mathrm{TB}$, whereas the number of TB effected male and female in Dhulli locality was $(n=02)$. Bagh is the urban area while Dhulli and Thub are both rural areas. High TB infections among the individuals of Thub locality indicates that people of this locality might have poor socioeconomic status, lack of awareness, poor hygienic conditions or unavailability of health facilities. These results were supported by research done by Hart (2013) earlier.

It was observed that overall estimated prevalence of TB was high $(\mathrm{n}=04)$ in females as compared to males ( $\mathrm{n}$ $=03$ ); the overall estimated percentage TB prevalence on the gender base was 01 and $1.33 \%$, respectively. Khalid et al. (2013) also reported that in Azad Jammu and Kashmir, the prevalence of TB in females was approximately $52 \%$ of all TB patients in 2010. These results were confirmed by the study carried out by Sabawoon and Sato (2012), in which the reported prevalence of TB was high (68.5\%) in females than males (31.5\%) in Afghanistan. However, these results were different from the reported results of Chen et al. (2014), in which the annual TB prevalence in male was found higher $(111.75 / 100000)$ than females (43.44/100000). It was also observed that the individual's positive for TB had disorders such as confections cough, flue, sore throat, jaundice, anemia etc. The individuals positive for TB were divided into different age groups ranging from 4-17 years. Results showed that the individuals of two age groups (4-8, 13-17 years) had same $(\mathrm{n}=02)$, TB prevalence, whereas the individuals of remaining age group (9-12 years) had high prevalence (n $=03$ ); the percentage prevalence of TB was found higher $(42 \%)$ in individuals of 9-12 years as compared to other age group (4-8, 13-17 years) individuals, with equal $(28 \%)$ percentage prevalence. These results were further confirmed by the reported results of Syed et al. (2012) in which the highest prevalence $(37.2 \%)$ of TB was found in the children having the age of 6-12 years.

The results also showed that among the TB infected individuals $(\mathrm{n}=07)$, only five were physically weak while no underweight individual was reported from all studied localities. Among the total population from each of three localities (Thub, Dhulli and Bagh), three (60\%) weak children were reported from Thub, two (40\%) weak children were located in Dhulli area while no case of weak individual was observed in Bagh locality.

The surveyed population was also subjected to medical checkup in order to estimate the prevalence of different diseases. Results revealed that in Thub, Bagh and Dhulli localities, the number of diseased children was 5, 1 and 2, respectively. Similarly four weak children were reported in Thub locality and two in Dhulli locality, whereas no case for weak child was reported from Bagh locality. The reported diseases in all localities included allergy, cough mild flue, sore throat, dental oral hygiene bad anemia, cough severe jaundice, tuberculosis hepatitis C, skin allergies, and scabies. Same results were reported by Heda and Nawal (2013), in which signs and symptoms like cough, weight loss, fever, night sweat etc. were found common in TB reported patients. These results were further supported in a study carried out by Gilani and Khurram (2012), in which fever, cough etc. were found common among TB patients.

The assessment of previous life history of under privileged orphans regarding the risk factors associated for hepatitis $\mathrm{B}$ and $\mathrm{C}$ showed that the overall prevalence of hepatitis $\mathrm{C}$ was low (2\%) in total 300 underprivileged children of District Bagh whereas no case of hepatitis $\mathrm{B}$ was found because low number of respondents were exposed to hepatitis $\mathrm{B}$ and $\mathrm{C}$ associated risk factors. The study showed that minimum number of respondents were exposed to positive family history of jaundice and hepatitis $(2 \%)$, history of vaccination $(0.66 \%)$, screening history $(1.66 \%)$, history of hepatitis patient ( $2 \%)$, AIDS/diabetes/ TB $(2 \%)$, blood transfusion $(3 \%)$, dental treatment $(5 \%)$, major or minor surgery $(2 \%)$, hospitalization, tattooing/ piercing, visit to beauty parlor (1\%), sexual behavior $(0 \%)$, organ transplantation and renal dialysis $(0 \%)$. This study is similar to that of Awadalla et al. (2011) that all these factors are significantly responsible for HCV transmission. Similar results for hepatitis B were reported by Machado et al. (2013). Our results for hepatitis B and C were also 
supported by Kaur et al. (1996).

Although all respondents were exposed to the risk factor of accidental pricking or cut throughout their life the prevalence of hepatitis B and C is low among them. Our study has contradiction with the study of Ashraf et al. (2010), who reported that history of drugs and injections, accidental cut and pricking with needle are most significant risk factor for developing hepatitis $\mathrm{B}$ and $\mathrm{C}$.

The evaluation of previous life history of under privileged orphans, regarding the risk factors associated for TB suggests that prevalence of TB is low in under privileged male and female orphan's population of District Bagh because less number of respondents were exposed to the risk factors inspite of positive family history of TB $(02.66 \%)$, deficiency of separate kitchen and sharing of bed room more than two or four family members. This result is supported by Karim et al. (2012) that the children living in houses with separate kitchen, having two or more bed rooms and with the negative family history of TB had a less chance of developing TB. The findings showed that exposure to smoke (17\%) was less reported by respondents and their family members. Same result is reported by Kolappan et al. (2007) which reported that smoker are at 2.1 time's greater risk for developing TB as compared to nonsmokers.

Our findings suggest low prevalence of TB because higher number of respondents were not exposed to history of inhaler use or allergy medications, diabetes, HIV/ AIDS or any other diseases (5\%), history of TB, sign/ symptoms of active tuberculosis (1\%), use of prescription medications $(0 \%)$, history of intestinal bypass $(0 \%)$, renal dialysis $(0 \%)$, poor ventilation and indoor outdoor pollution like having no room for cattle. This study is supported by the Narasimhan et al. (2013) who reported that person with history of all these risk factors are more prone to TB disease.

The study revealed that highest number of individuals were exposed to the wood fuel $(97 \%)$ for cooking as compared to dung fuel and LPG gas, yet prevalence of TB among these participants was found low. Current study contradicts with study of Shetty et al. (2006) that cooking with electricity or gas has lowest risk of developing TB as compared to the cooking with coal, wood, cow dung. Similarly, consumption of milk products and history of drugs and injections highest number of individuals are exposed to this risk factors but prevalence is low.

\section{CONCLUSION AND RECOMMENDATIONS}

Although the prevalence of hepatitis B, C and TB among selected population was low but further studies are required to create awareness and reduce the spread of these diseases among peripheral communities of Azad Jammu and Kashmir.

\section{ACKNOWLEDGMENTS}

Hepatitis Society University of Azad Jammu and Kashmir Muzaffarabad and Health Care Diagnostic and Research Centre, Muzaffarabad are gratefully acknowledged for their active involvement in this study. A special thanks to Help In Need (HIN) for their support in the organizing screening camps and provision of other facilitations regarding the present study.

\section{Ethical approval and consent to participants}

The study was approved by the Directorate of Advanced Studies and Research (DAS\&R), which have authority to approve research topics and it also deals with ethical issues in University of Azad Jammu and Kashmir, Muzaffarabad. Filled and signed participation consent was collected from each participant and from their guardians before the sampling. All the information of the participants kept confidentially and laboratory testing and results provision were free of cost.

\section{Availability of data and materials}

The data is present in soft copy form (Excel sheet) as well as in the form of paper document and all the amplified samples are also present in our diagnostic centre, which will be provided to the journal on demand. Any audio and video data did not obtained during the study.

\section{Statement of conflict of interest}

We hereby declare that we have no competing interests with any other author or reviewer.

\section{REFERENCES}

Alter, M.J., Kruszon M.D., Nainan, O.V., Mcquilla, G.M., Gao, F., Moyer, L.A., Kaslow, R.A. and Margolis, H.S., 1999. The prevalence of hepatitis C virus infection in the United States, 1998 through 1994. New Engl. J. Med., 341: 556-562. https://doi. org/10.1056/NEJM199908193410802

Butt, T. and Amin, M.S., 2008. Seroprevalence of hepatitis $\mathrm{B}$ and $\mathrm{C}$ infections among young adult males in Pakistan. East. Mediterr. Hlth. J., 14: 791794.

Casanova, Y.S., Boeira, T.R., Sisti, E., Celmer, A., Fonseca, A.S.K., Ikuta, N., Simon, D. and Lunge, V.R., 2014. A complete molecular biology assay for hepatitis $\mathrm{C}$ virus detection, quantification and genotyping. Rev. Soc. Brasil. Med. Trop., 47: 287- 
294. https://doi.org/10.1590/0037-8682-0040-2014

Chomczynski, P. and Mackey, K., 1995. Short technical report. Modification of the TRIZOL reagent procedure for isolation of RNA from Polysaccharide-and proteoglycan-rich sources. Biotechniques, 19: 942-945.

Ghany, M.G., Strader, D.B., Thomas, D.L. and Seeff, L.B., 2009. Diagnosis, management and treatment of hepatitis C: An update. Hepatology, 49: 1335 1374. https://doi.org/10.1002/hep.22759

Gravitz, L., 2011. A smouldering public-health crisis. Nature, 474: 2-4. https://doi.org/10.1038/474S2a

Habib, M., Mohamed, M., Abdel, A.F., Maqder, L.S., Abdel, H.M., Gmail, F., Madkour, S., Mikhail, N.N., Anwer, W., Strickland, G.T., Fix, A.D. and Sallam, I., 2001. Hepatitis C virus infection in a community in Nile Delta: Risk factors for seropositivity. Hepatology, 33: 248-253. https:// doi.org/10.1053/jhep.2001.20797

Idrees, M., Rafique, S., Rehman, I., Akbar, H., Yousaf, M.Z., Butt, S., Awan, Z., Manzoor, S., Akram, M. and Aftab, M., 2009. Hepatitis C virus genotype 3a infection and hepatocellular carcinoma: Pakistan experience. World J. Gastroenterol., 15: 50805085. https://doi.org/10.3748/wjg. 15.5080

Kidd-Ljunggren, K., Holmberg, A., Bläckberg, J. and Lindqvist, B., 2006. High levels of hepatitis B virus DNA in body fluids from chronic carriers. J. Hosp. Infect., 64: 352-357. https://doi.org/10.1016/j. jhin.2006.06.029

Konstantinos, A., 2010. Testing for tuberculosis. Aust. Prescr., 33: 12-18. https://doi.org/10.18773/ austprescr.2010.005

Kumar, V., Abbas, A.K., Fausto, N. and Mitchell, R.N., 2007. Robbins basic pathology, $8^{\text {th }}$ ed. Saunders Elsevier, Philadelphia, pp. 516-522.

Lee, W.M., 1997. Hepatitis B virus infection. New Engl. J. Med., 3: 1733-1745. https://doi.org/10.1056/ NEJM199712113372406

Mahoney, F.J., 1999. Update on diagnosis, management, and prevention of hepatitis B virus infection. Clin. Microbiol. Rev., 12: 351-366. https://doi. org/10.1128/CMR.12.2.351

Mumtaz, S., Rehman, M.U., Muzaffar, M., Hassan, M.U. and Iqbal, W., 2002. Frequency of seropositive blood donors for hepatitis B, C and HIV viruses in Railway Hospital Rawalpindi. Pak. J. med. Res., 41: 2 .

Ohno, T., Mizokami, M., Wu, R.R., Saleh, M.G., Ohba, K.I., Orito, E., Mukaide, M., Williams, R. and Lau, J.Y.N., 1997. New hepatitis C virus (HCV) genotyping system that allows for identification of HCV genotypes 1a, 1b,2a, 2b, 3a, 3b, 4, 5a, and 6a. J. clin. Microbiol., 35: 201-207.

Rauf, A., Nadeem, M.S., Riaz, H., Latif, M.M., Latif, M.Z., Ahmed, N. and Shakoori, A.R., 2013. Tuberculosis and hepatitis infections among the underprivileged orphan children of Northern Pakistan. Pakistan J. Zool., 45: 1765-1770.

Reddy, M.M., Saira, M. and Kumar, P.S., 2012. A strategic review on disease prospective of hepatitis-A. J. Res. Pharm. Biomed. Sci., 3: 656661.

Shamsi, T., Hashmi, K., Adil, S., Ahmad, P., Irfan, M., Raza, S., Masood, N., Shaikh, U., Satti, T., Farzana, T. and Ansari, S., 2008. The stem cell transplant program in Pakistan the first decade. Bone Marrow Transpl. Suppl., 42: 114-119. https:// doi.org/10.1038/bmt.2008.137

Sharma, S.D., 2010. Hepatitis C virus: Molecular biology and current therapeutic options. Indian $J$. med. Res., 131: 17-34.

Strader, D.B., Wright, T., Thomas D.L. and Seeff, L.B., 2004. Diagnosis, management, and treatment of hepatitis C. Hepatology, 39: 1147-1171. https://doi. org/10.1002/hep.20119

Van Deun, A., Aung, K.J., Salim, A.H., Gumusboga, M., Nandi, P. and Hossain, M.A., 2010. Methylene blue is a good background stain for tuberculosis light-emitting diode fluorescence microscopy. Int. J. Tuberc. Lung Dis., 14: 1571-1575.

Waheed, Y., Safi, S.Z. and Qadri, I., 2011. Role of potash alum in hepatitis $\mathrm{C}$ virus transmission at barber's shop. Virol. J., 8: 211. https://doi.org/10.1186/1743422X-8-211

Wanderlei-Silva, D., Nobre, M., Gonzaga, R.S., Viana, L.S. and Neto, E.R., 2005. High quality DNA from human papillomavirus (HPV) for PCR/RFLPs. Brazil. Arch. Biol. Technol., 48: 37-40. https://doi. org/10.1590/S1516-89132005000100006

WHO, 2000. Hepatitis B: World Health Organization Fact Sheet 204 (Revised October 2000). World Health Organization, Geneva.

WHO, 2009. Global tuberculosis control surveillance, planning, and financing. World Health Organization, Geneva, pp. 1-303.

WHO, 2010. Treatment of tuberculosis: Guidelines for national programs, $4^{\text {th }}$ ed. World Health Organization, Geneva.

WHO, 2011. Global tuberculosis control report. World Health Organization, Geneva. 